\title{
Simple static hydroponic technology of Chenopodium quinoa Willd
}

\author{
Rongxia Fu' ${ }^{l}$, Ming Yang ${ }^{2}$, Xueyong $\mathrm{Zhou}^{l^{*}}$, Cong Zhao ${ }^{3}$, Yan Cui ${ }^{1}$ \\ ${ }^{1}$ College of Food Science and Bioengineering, Tianjin Agriculture University, Tianjin300384, PR China; \\ ${ }^{2}$ Class 7, Grade 10, Tianjin Middle School, Tianjin300384, PR China \\ ${ }^{3}$ School of Management ,Jilin University, Jilin130022,PR China \\ * Corresponding author: Xueyong Zhou. *e-mail address: zhouxueyongts@163.com.
}

\begin{abstract}
As a new type of "foreign vegetable", Chenopodium quinoa Willd vegetable is delicious and nutritious. However, the field cultivation of quinoa is affected by the soil, temperature and precipitation. At the present study, a simple static hydroponics method for quinoa cultivation was investigated. The results showed that both fresh weight and dry weight of Chenopodium quinoa Willd vegetable increased rapidly during the growth period of 18-28 days, and after 28 days, the increase rate became slow. The plant height of quinoa ranged from $12.55 \pm 1.77 \mathrm{~cm}$ to $23.91 \pm 2.54 \mathrm{~cm}$ between 18 and 38 days. The static hydroponics provided an alternative method for quinoa cultivation.
\end{abstract}

\section{Introduction}

Chenopodium quinoa Willd is native grain crop in South America and its cultivation history has been more than 7000 years. It is a kind of "total nutritious food", which is known as "the mother of grains". Not only is it rich in protein, but also it contains all essential amino acids. In addition, it is also rich in unsaturated fatty acids, vitamins, minerals and a variety of bioactive substances, such as polyphenols, flavonoids, saponins and tannin, which are beneficial to health. At present, quinoa has been planted in many places in China, but the variety selection and cultivation technology have yet to be improved. Moreover, quinoa is suitable for cultivation in high-altitude areas and has strict climate restrictions, therefore, it is difficult to plant quinoa in estern China. However, as far as the quinoa seedling is concerned, there are no region restrictions for its planting. Since the Colombian era, the leaves of quinoa have been eaten by native people. It was reported that quinoa leaves contain a variety of nutrient ingradients, such as carotene, vitamin $\mathrm{E}$, vitamin $\mathrm{C}$ and microelements. The content of arotene in quinoa leaves is between 230.23 and $669.57 \mathrm{mg} / \mathrm{kg}^{[1]}$, which is higher than spinach and amaranth ${ }^{[2-4]}$. The content of vitamin $\mathrm{E}(\alpha-\mathrm{TE})$ and vitamin $\mathrm{C}$ is $29 \mathrm{mg} / \mathrm{kg}$ and $1.2-2.3 \mathrm{~g} / \mathrm{kg}^{[5]}$, resectively. The contents of calcium, iron and zinc in quinoa leaves is $3583-9601 \mathrm{mg} / \mathrm{kg}$, 5.6-7.9 $\mathrm{mg} / \mathrm{kg}$ and $0.7-42.6 \mathrm{mg} / \mathrm{kg}$, respectively. The contents of protein, lipid and cellulose in quinoa leaves is $2.79-4.17 \%, 1.9-2.3 \%$ and $1.9 \%$, respectively ${ }^{[6]}$. The antioxidation ingredients in quinoa leaves slow down the proliferation of cancer cells, anti-inflammatory, anti microbial and other aspects ${ }^{[7,8]}$.
In the recent ten years, quinoa has been cultivated as a grain in China, and the planting area was approximate to 12000 hectare. Up to now, the total output of quinoa grain is about 21600 tons per year. However, few attempts have been made to grow quinoa as a vegetable. At the present study, the simple hydroponic method for the cultivation of quinoa seedling was carried out. Unlike the traditional hydroponics, the simple static hydroponics method requires to buy a set of hydroponics cultivation facilities, but it does not need soils, which is beneficial to alleviate the shortage of urban land resources in China. Therefore, the hydroponic method of quinoa has a bright development prospect ${ }^{[10]}$.

\section{MATERIALS and METHODS}

\subsection{Variety selection}

The Qingli II of Chenopodium quinoa Willd cultivated by Qinghai Academy of Agricultural and Forestry Sciences is selected as the experimental material.

\subsection{Preparation of nutrient solution}

The nutrient ingredients is the Hoagland general formula. The nutrient ingredients can be dissolved by tap water, reservoirs water, well water, non-polluted river water and rain water. The dosage of main compounds in formula is shown in Table 1, and the dosage of trace elements is shown in Table 2.

Table 1. Dosage of main compounds in the Hoagland general formula. 


\begin{tabular}{|c|c|c|c|c|c|}
\hline Formula's & \multicolumn{4}{|c|}{ Dosage of main compounds (mg/L) } \\
\cline { 2 - 6 } $\begin{array}{c}\text { name of } \\
\text { nutrient } \\
\text { solution }\end{array}$ & $\begin{array}{c}\mathrm{Ca}\left(\mathrm{NO}_{3}\right)_{2} \cdot \\
4 \mathrm{H}_{2} \mathrm{O}\end{array}$ & $\mathrm{KNO}_{3}$ & $\begin{array}{c}\mathrm{NH}_{4} \mathrm{H}_{2} \mathrm{PO} \\
4\end{array}$ & $\begin{array}{c}\mathrm{MgSO}_{4} \\
7 \mathrm{H}_{2} \mathrm{O}\end{array}$ & $\begin{array}{c}\text { Total } \\
\text { salts }\end{array}$ \\
\hline $\begin{array}{c}\text { Hoagland } \\
\text { general } \\
\text { formula }\end{array}$ & 945 & 607 & 115 & 493 & 2160 \\
\hline
\end{tabular}

Table 2. Dosage of trace elements in the Hoagland general formula.

\begin{tabular}{|c|c|c|}
\hline Name of compound & $\begin{array}{c}\text { Dosage of } \\
\text { compounds } \\
(\mathbf{m g} / \mathbf{L})\end{array}$ & $\begin{array}{c}\text { Content of } \\
\text { trace element } \\
(\mathbf{m g} / \mathbf{L})\end{array}$ \\
\hline $\begin{array}{c}\mathrm{Na}_{2} \mathrm{Fe}-\mathrm{EDTA} \\
(\text { contains } \mathrm{Fe} 14.0 \%)\end{array}$ & 20 & 2.8 \\
\hline $\mathrm{H}_{3} \mathrm{BO}_{3}$ & 2.86 & 0.5 \\
\hline $\mathrm{MnSO}_{4} \cdot 7 \mathrm{H}_{2} \mathrm{O}$ & 2.13 & 0.5 \\
\hline $\mathrm{ZnSO}_{4} \cdot 7 \mathrm{H}_{2} \mathrm{O}$ & 0.22 & 0.05 \\
\hline $\mathrm{CuSO}_{4} \cdot 5 \mathrm{H}_{2} \mathrm{O}$ & 0.08 & 0.02 \\
\hline$\left(\mathrm{NH}_{4}\right)_{6} \mathrm{Mo}_{7} \mathrm{O}_{24} \cdot 4 \mathrm{H}_{2} \mathrm{O}$ & 0.02 & 0.01 \\
\hline
\end{tabular}

\subsection{Cultivatrion of quinoa by hydroponic tray}

Double trays were used for the quinoa hydroponics. The size of outer tray is $32.7 \times 26.5 \times 4 \mathrm{~cm}$ (length $\times$ width $\times$ height), and the size of internal tray is $32.7 \times 26.5 \times 3 \mathrm{~cm}$. The distance between both bottoms is 1 $\mathrm{cm}$. The bottom of the internal tray has punched holes, and a draining net $(20 \mathrm{mesh})$ is put on the upper layer of the hollowed hydroponic tray. The vermiculite was put on the draining net until the height is about $5 \mathrm{~mm}$. The quinoa seeds were planted in the vermiculite to a depth of $1 \mathrm{~cm}$. The vermiculite was watered once each day until the quinoa root grew through the draining net. The nutrient solution was put into the outer hydroponic tray until the quinoa root could reach the nutrient solution. The vermiculite was stopped to water and quinoa seedling started to absorb the nutrient solution to grow.

\subsection{Management method}

The sowing rate is $0.3-0.5 \mathrm{~g}$ per tray (amount to $2-4 \mathrm{~kg}$ per $667 \mathrm{~m}^{2}$ ). The nutrient solution height is appropriately about $1 \mathrm{~cm}$. The hydroponic tray is laid in a dark place and is sprayed by water one time a day. After three days, hydroponic tray is moved into a place with sufficient sunlight, the temperature should be above $8^{\circ} \mathrm{C}$ at night and below $35^{\circ} \mathrm{C}$ during the day. From then on, there is no need to spray water on the vermiculite as the quinoa roots of the seedlings have already touched the nutrient solution surface in the hydroponic tray. During the first 10 days, the diluted nutrient solution can be used as the quinoa seedling can continuously grow by using its own seed nutrition. Afterwards, in order to ensure the vigorous growth of quinoa seedlings, the concentrated Hoagland nutrient solution should be used. Because the nutrient solution is easily evaporated, it should be supplemented everyday so that the roots of the quinoa seedlings can touch the liquid surface. Nevertheless, the upper part of the nutrient solution cannot be touched the vermiculite, thus, the quinoa roots can be exposed to the air above the solution.

\subsection{Temperature management}

Quinoa has the characteristics of low temperature resistance but has no high temperature resistance. In general, the maximum temperature cannot exceed $35^{\circ} \mathrm{C}$, and the suitable growth temperature is about $20^{\circ} \mathrm{C}$. During the cultivation of Chenopodium quinoa Willd vegetables, the temperature at night should be maintained above $8^{\circ} \mathrm{Cand}$ below $35^{\circ} \mathrm{Cduring}$ the day.

\subsection{Light adjustment}

Natural light can meet the quinoa requirement during the whole growth period. In order to make quinoa vegetables grow well, the hydroponics tray should be placed in a sunny place, and at least 3-4 hours of light time should be guaranteed every day. If artificial lighting is used, it is suggested that 8 hours of lighting and 16 hours of dark cycle can be used.

\subsection{Disease and pest control}

Quinoa vegetables have strong disease resistance. Because the growth period of quinoa seedling is short, only few diseases occur. Occasionally, there is leaf spot disease. If the disease is found, the whole plants should be pulled out. There are almost no insect pests in the growth period of quinoa seedling vegetables.

\subsection{Test indexes}

After sowing 3 days, it was needed to record the time of the emergence of seedlings, two true leaves and four true leaves. The quinoa vegetables were randomly selected at 18th, 23rd, 28th, 33rd and 38th days after sowing, then the plant height, leaf length, leaf width, and stem diameter were measured by using a vernier calliper. In addition, 50 fresh quinoa seedling vegetables should be taken. After drying in an electric thermostatic blast dryer, the fresh and dried weight of quinoa seedling were obtained. Moreover, the quality of quinoa seedling is determined by sensory quality evaluation. The sensory scoring criteria are shown in Table 3.

Table 3. Evaluation criteria of sensory quality of Chenopodium quinoa Willd vegetables.

\begin{tabular}{|c|c|c|}
\hline \multirow{2}{*}{ Indicators } & Characteristics & $\begin{array}{c}\text { Scoring } \\
\text { range }\end{array}$ \\
\hline \multirow{2}{*}{$\begin{array}{c}\text { Freshness } \\
(25 \text { scores })\end{array}$} & Fresh, crisp & $20 \sim 25$ \\
\cline { 2 - 3 } & Relatively Fresh, relatively crisp & $10 \sim 19$ \\
\cline { 2 - 3 } & Turn tender, no crisp & $0 \sim 9$ \\
\hline \multirow{2}{*}{$\begin{array}{c}\text { Color and } \\
\text { luster } \\
(25 \text { scores })\end{array}$} & \begin{tabular}{c} 
Bright green, normal color \\
\cline { 2 - 3 }
\end{tabular} & $20 \sim 25$ \\
\hline
\end{tabular}




\begin{tabular}{|c|c|c|}
\hline & Yellowing $<10 \%$, poor color & $0 \sim 9$ \\
\hline \multirow{2}{*}{$\begin{array}{c}\text { Organizatio } \\
\text { nal status } \\
(25 \text { scores })\end{array}$} & $\begin{array}{c}\text { Flat Leaf edge, no aging, good } \\
\text { shape }\end{array}$ & $20 \sim 25$ \\
\cline { 2 - 3 } & $\begin{array}{c}\text { Relative flat Leaf edge, relative } \\
\text { good shape }\end{array}$ & $10 \sim 19$ \\
\cline { 2 - 3 } & Curled leaf edge, aging $<10 \%$ & $0 \sim 9$ \\
\hline \multirow{2}{*}{$\begin{array}{c}\text { Taste } \\
(25 \text { scores })\end{array}$} & $\begin{array}{c}\text { Soft, good chewability, unique } \\
\text { fragrance }\end{array}$ & $20 \sim 25$ \\
\cline { 2 - 3 } & $\begin{array}{c}\text { Moderate,relatively good } \\
\text { chewability, light fragrance }\end{array}$ & $10 \sim 19$ \\
\cline { 2 - 3 } & $\begin{array}{c}\text { Hard, poor chewability, no clear } \\
\text { fragrance }\end{array}$ & $0 \sim 9$ \\
\hline
\end{tabular}

\section{Results and analysis}

\subsection{The growth periods of hydroponic quinoa vegetables}

The growth periods of hydroponic quinoa vegetables are shown in Table 4. According to the instructions of the seeds, it takes 5-7 days to emerge in the field, it takes about 15-20 days to grow two true leaves, and it takes about 25-28 days to grow four true leaves. It can be seen from Table 4 that the Chenopodium quinoa Willd cultivated by hydroponic method started to germinate after three days of sowing, which was earlier than that planted in the soils. The appearance of two true leaves in nutrient solutiona was 2 to 5 days earlier than those in soils, and the appearance of four true leaves in nutrient solution was 4 to 7 days earlier than those in soils. The above results indicated that the hydroponic cultivation of quinoa vegetables can shorten the growth periods.

Table 4. Growth periods of hydroponic Chenopodium quinoa Willd vegetables.

\begin{tabular}{|c|c|c|c|c|}
\hline $\begin{array}{c}\text { Sowing } \\
\text { date }\end{array}$ & $\begin{array}{c}\text { Germin } \\
\text { ation } \\
\text { (day) }\end{array}$ & $\begin{array}{c}\text { Emerge } \\
\text { nce rate } \\
\text { (\%) }\end{array}$ & $\begin{array}{c}\text { Grow two } \\
\text { true leaves } \\
\text { (day) }\end{array}$ & $\begin{array}{c}\text { Grow four } \\
\text { true leaves } \\
\text { (day) }\end{array}$ \\
\hline $\begin{array}{c}\text { March } \\
\text { 25th }\end{array}$ & $3-5$ & 93 & $13-15$ & $21-23$ \\
\hline
\end{tabular}

\subsection{Agronomic traits of Chenopodium quinoa Willd vegetables at different growth time}

The agronomic traits of Chenopodium quinoa Willd vegetables at different growth time is shown in table 5 . With the extension of the growth time, the plant height, leaf length, leaf width, stem diameter and leaf number of Chenopodium quinoa Willd vegetables initally increased rapidly, then gradually became slow. After 38 days of cultivation, the sensory evaluation of quinoa decreased but the yield reach the highest. Although the 18-day-cultivated Chenopodium quinoa Willd vegetables are fresh and tender, the yield is quite low and the cost of cultivation is high.

Table 5. Agronomic traits of Chenopodium quinoa Willd vegetables at different growth time.

\begin{tabular}{|c|c|c|c|c|c|}
\hline $\begin{array}{c}\text { Growth } \\
\text { time }\end{array}$ & $\begin{array}{c}\text { Plant } \\
\text { height } \\
\text { (cm) }\end{array}$ & $\begin{array}{c}\text { Leaf } \\
\text { length } \\
\text { (cm) }\end{array}$ & $\begin{array}{c}\text { Leaf } \\
\text { width } \\
\text { (cm) }\end{array}$ & $\begin{array}{c}\text { Stem } \\
\text { diam } \\
\text { eter } \\
\text { (mm) }\end{array}$ & $\begin{array}{c}\text { Leaf } \\
\text { number } \\
\text { (piece) }\end{array}$ \\
\hline \multirow{2}{*}{18} & $\begin{array}{c}12.55 \pm \\
1.77\end{array}$ & $\begin{array}{c}1.70 \pm \\
0.35\end{array}$ & $\begin{array}{c}1.15 \pm \\
0.27\end{array}$ & $\begin{array}{c}0.73 \pm \\
0.18\end{array}$ & $2.0 \pm 0$ \\
\hline 23 & $\begin{array}{c}13.90 \pm \\
1.37\end{array}$ & $\begin{array}{c}2.10 \pm \\
0.32\end{array}$ & $\begin{array}{c}1.71 \pm \\
0.29\end{array}$ & $\begin{array}{c}1.38 \pm \\
0.42\end{array}$ & $4.0 \pm 1.3$ \\
\hline 28 & $\begin{array}{c}20.25 \pm \\
2.04\end{array}$ & $\begin{array}{c}2.73 \pm \\
0.51\end{array}$ & $\begin{array}{c}2.10 \pm \\
0.52\end{array}$ & $\begin{array}{c}1.51 \pm \\
0.27\end{array}$ & $7.0 \pm 1.0$ \\
\hline 33 & $\begin{array}{c}23.73 \pm \\
2.76\end{array}$ & $\begin{array}{c}2.97 \pm \\
0.40\end{array}$ & $\begin{array}{c}2.60 \pm \\
0.31\end{array}$ & $\begin{array}{c}1.63 \pm \\
0.37\end{array}$ & $9.1 \pm 1.2$ \\
\hline 38 & 23.91 & $3.47 \pm 0$. & $3.06 \pm$ & $2.20 \pm$ \\
\pm 2.54 & 52 & 0.60 & 0.43 & $10.0 \pm 1.4$ \\
\hline
\end{tabular}

\subsection{Fresh weight and dry weight of quinoa vegetables at different growth time}

Fresh weight is a common indicator of the moisture status of plant tissues. For normal growing tissues, the amount of water content can elucidate the growth status of the plant to a certain extent. The dry weight reflect the amount of nutrient substances, so it is very important to measure the fresh and dry weight of quinoa. It can be seen from Table 6 that both fresh and dry weight of quinoa vegetables increased rapidly during the growth period of 18-28 days, and after 28 days, the increase rate became slow. During the growth period of 18-38 days, dry matter content showed a slowly increasing trend, indicating that the nutrient ingredients are gradually accumulating. Although the fresh and dry weight reached the maximum at harvest time of the 38 days, considering the production efficiency and economic benefits, 28-33 days are the appropriate harvest period.

Table 6. Comparison of fresh and dry weight of Chenopodium quinoa Willd vegetables at different growth time.

\begin{tabular}{|c|c|c|c|}
\hline $\begin{array}{c}\text { Growth } \\
\text { time }\end{array}$ & $\begin{array}{c}\text { Fresh } \\
\text { weight(g) }\end{array}$ & $\begin{array}{c}\text { Dry } \\
\text { weight(g) }\end{array}$ & $\begin{array}{c}\text { Dry matter } \\
\text { content(\%) }\end{array}$ \\
\hline 18 & 59.24 & 4.57 & 7.71 \\
\hline 23 & 87.31 & 7.29 & 8.35 \\
\hline 28 & 141.95 & 14.53 & 10.24 \\
\hline 33 & 147.69 & 16.41 & 11.10 \\
\hline 38 & 154.98 & 17.43 & 11.25 \\
\hline \multicolumn{4}{|c|}{ Dry matter content $(\%)=\frac{\text { Dry weight }}{\text { Fresh weight }} \times 100 \%$} \\
\hline
\end{tabular}

The dry matter content was calculated according to equation (1). It can be seen form Table 6 that the dry matter contentonly had a little change between 28th day and 33rd day.

\subsection{Sensory quality evaluation of quinoa vegetables at different growth time}

It can be seen from Table 7 that the sensory score of quinoa harvested at 28 th day was the highest, and the sensory score of quinoa harvested at 18 th day was the lowest. According to the results of sensory quality evaluation, it is suitable for quinoa seedling to be harvested between 28 th day to 33 rd day after cultivation. 
Table 7. Sensory quality evaluation of quinoa vegetables at different growth time.

\begin{tabular}{|c|c|}
\hline Growth time (day) & Sensory scores \\
\hline 18 & $81.1 \pm 8.3$ \\
\hline 23 & $82.6 \pm 15.4$ \\
\hline 28 & $89.1 \pm 7.9$ \\
\hline 33 & $87.6 \pm 9.7$ \\
\hline 38 & $83.3 \pm 7.1$ \\
\hline
\end{tabular}

\section{Conclusion}

The plant height, leaf length, leaf width, stem diameter, leaf number, fresh weight, dry weight and sensory quality evaluation of quinoa vegetable are important indicators, which are related to the quality of quinoa vegetable. The research results indicated that quinoa seedling can be cuntivated in nutirent solution, and the suitable harvest time of quinoa vegetable is between 28th to 33rd after sowing. The static hydroponics provided an alternative method for quinoa cultivation.

\section{Acknowledgements}

The research was funded by the Tianjin Key Projects of Scientific and Technological Support (18YFZCNC01270).

\section{References}

1. Bhargava, S. Shukla, D. Ohri. Genetic variability and interrelationship among various morphological and quality traits in quinoa. Field Crops Research, 2007, 101, 104-116.

2. S. Shukla, V. Pandey, G. Pachauri, B.S. Dixit, R. Bannerji, S.P. Singh. Nutritional contents of different foliage cuttings of vegetable amaranth. Plant Foods for Human Nutrition, 2003, 58, 1-8.

3. Prakash, M. Pal. Nutritional and anti nutritional composition of vegetable and grain amaranth leaves. Journal of the Sciences of Food and Agriculture, 1991, 57, 573-583.
4. K. Gupta, D.S. Wagle. Nutritional and antinutritional factors of green leafy vegetables. Journal of Agricultural and Food Chemistry, 1988, 36, 472-474.

5. M. J. Koziol. Chemical composition and nutritional value of quinoa. Journal of Food Composition and Analysis 1992, 5, 35-68.

6. Cornejo, de Z.G. Hojas de quinua fuente de protein. In: Segunda Convencion Internacional de Quenopodiaceas, Universidad Boliviana Tomas Frias, Comite Departamental de Obras Publicas de Potosi, Instituto Interamericano de Ciencias Agricolas, Potosi, Bolivia, 1976, pp.177-180.

7. Q. A. Meneguetti, M. A. Brenzan, M. R.Batista, R.B. Bazotte, D.R.Silva, C. D. A.Garcia. Biological effects of hydrolyzed quinoa extract from seeds of Chenopodium quinoa Willd. Journal of Medicinal Food, 2011, 14(6), 653-657.

8. L. E Abugoch James. Quinoa: composition, chemistry, nutritional and functional properties. Advances in Food \& Nutrition Research, 2009, 58, $1-31$.

9. B Peng. Greenhouse cultivation technology of hydroponic vegetables. China Agricultural Technology Extension, 2019, 35 (4), 50-51.

10. X. Z. Liu, Z. Y. Li, H. H. Liu. Cultivation techniques of static hydroponics spinach. Journal of Changjiang Vegetables, 2019, 23, 35-36. 